$\S=-1$

\title{
Post Project Assessment of Risk in Construction Projects
}

\author{
N.Naveen ${ }^{1}$, Nadendla Harshit ${ }^{2}$, D Muthu ${ }^{3}$, C Venkatasubramaniam ${ }^{4}$, P.Sharmila ${ }^{5}$ \\ School of Civil Engineering Sastra Deemed To Be University, Thanjavur, Tamilnadu, India \\ *Corresponding Author Email: ${ }^{1}$ naveen141993@gmail.com, ${ }^{2}$ harshithnadendla1997@ gmail.com, \\ ${ }^{3}$ dmuthu@civil.sastra.edu, ${ }^{4}$ cv@civil.sastra.edu ${ }^{5}$ sharmila@civil.sastra.edu
}

\begin{abstract}
In these days construction projects are applied in risky and unstable environments results in a very high risk factors and unreliability. Risk assessment is a way to conclude the risks and quandary of the project executed and directs it with some actual solutions. In this field the top managements authority need to detect the value, phase, grade and status of the project. Since there is lot of different problems are intricate in construction and it is so hard to keep in existence of value, phase, grade and status as schedule. This paper recognizes the factors required in the projects of construction field and to predict the possibilities which are affects the construction and reduction calculations. The probable risk factors available in the post project and it is categorized the very little effects to huge effects has been composed by the questionnaire survey. And the outcomes were look over by the SPSS software. The acceptable guidance was afforded to make over the negative issues.
\end{abstract}

Keywords: Risk management, Ranking offactors, Risk identification.

\section{Introduction}

In the project field the risk management comprises two important factors. They are the interception of potential issues and the advance identification of definite issues. These problems are majorly available in every project, daily basis works and almost in every organization. In present days risk management is a negative issue for a healthy management, as the projects are getting more difficult in present days. It is conceivable to breakdown venture risks from to alternate points of view. From the perspective of the customer who is vital to basic leadership in the task and form the perspective of the temporary worker, who customarily expands expenses to support risks, it given that the minor utility is getting lower, is confronting a training that has turned out to be and rewarding. These two gatherings have distinctive practice against the risks of the task and diverse conceivable outcome of exchanging risks to the gathering best ready to oversee them. As of now the act of risk management is receptive semi invariables, temporary and unstructured inside the construction development, bringing about an absence of ability to oversee chances fittingly.

The frame work utilizes for risk management in ventures has been essentially in view of subjective investigations, however the strategy does not permit to record risks, issues and moves made to determine them and additionally lessens realized with the goal that they can be utilized for the growth of a upcoming project. The accompanying is a posting of numerous development industry risks and exposures. The variable which impact the risks in the working amid development are recognized by the different developments.
The risk factors concluded are given below;

- Financial risk

- Legal risk

- Management risk

- Market risk

- $\quad$ Policy and political risk

- Technical risk

- Environmental risk

\section{Methodology}

The questionnaire contains 7 individual types of risks which contain various listed questions of risks involved

Section 1 - Respondents Data

Section 2 - Respondents Rating for the issues faced

The confront to confront personnel meet strategy is utilized for filling the survey and collecting the information in which the respondents make a brief clarification of the thoughts which are included in the survey. The survey conveyed at the destinations and information are collected through confront to confront meet strategy from the respondent. At that point the collected information are examined utilizing the taking after strategies.

1. Reliability, Validity test in IBM SPSS

2. Friedman mean test in IBM SPSS

Table 1: Reliability \& validity test

\begin{tabular}{|c|c|}
\hline \multicolumn{2}{|c|}{ Table 1: Reliability \& validity test } \\
\hline Cronbach's Alpha & N of items \\
\hline 0.97 & 72 \\
\hline
\end{tabular}

\begin{tabular}{|l|c|c|c|}
\hline \multicolumn{1}{|c|}{ Item statics } & mean & Stand deviation & N \\
\hline Bankruptcy of project partner & 1.800 & 1.562 & 30 \\
Loss due to fluctuation of inflation rate & 1.633 & 1.376 & 30 \\
Loss due to fluctuation of exchange rate & 2.000 & 1.508 & 30 \\
\hline
\end{tabular}




\begin{tabular}{|c|c|c|c|}
\hline Loss due to raise in fuel price & 2.400 & 1.499 & 30 \\
\hline Low creditability of shareholders and lenders & 1.667 & 1.493 & 30 \\
\hline Changes in bank formalities and regulations & 1.466 & 1.252 & 30 \\
\hline Insurance risk & 1.833 & 1.510 & 30 \\
\hline Breach of contract by project partner & 1.833 & 1.391 & 30 \\
\hline Lack of enforcement of legal judgment & 1.633 & 1.564 & 30 \\
\hline Improper verification of contract document & 2.000 & 1.438 & 30 \\
\hline Lack of knowledge of arbitration & 1.766 & 1.381 & 30 \\
\hline Uncertainty and unfairness of court justices & 1.800 & 1.517 & 30 \\
\hline No past experience in similar project & 1.666 & 1.422 & 30 \\
\hline Short tendering time & 1.933 & 1.311 & 30 \\
\hline Sub-contractor related problems & 2.566 & 1.430 & 30 \\
\hline Improper contractor feasibility study & 1.766 & 1.222 & 30 \\
\hline Improper project planning and budgeting & 1.933 & 1.484 & 30 \\
\hline Inadequate choice of project partner & 2.133 & 1.479 & 30 \\
\hline Improper project organization structure & 1.633 & 1.449 & 30 \\
\hline Poor relation and dispute with partner & 2.133 & 1.547 & 30 \\
\hline Internal management problems & 1.933 & 1.659 & 30 \\
\hline Team work & 2.066 & 1.680 & 30 \\
\hline Poor relation with government departments & 1.900 & 1.422 & 30 \\
\hline Time constrain & 1.866 & 1.547 & 30 \\
\hline Project delay & 2.330 & 1.561 & 30 \\
\hline Competition from other companies & 2.066 & 1.337 & 30 \\
\hline Fall short of expected income from project & 1.933 & 1.284 & 30 \\
\hline Increase of accessory facility price & 1.966 & 1.425 & 30 \\
\hline Increase of labour cost & 2.666 & 1.347 & 30 \\
\hline Increase of material price & 2.633 & 1.711 & 30 \\
\hline Increase of resettlement cost & 2.76 & 1.222 & 30 \\
\hline Inadequate forecast about market demand & 2.400 & 1.379 & 30 \\
\hline Local protectionism & 1.833 & 1.234 & 30 \\
\hline Unfairness in tendering & 1.800 & 1.214 & 30 \\
\hline Cost increase due to changes of government polices & 2.166 & 1.464 & 30 \\
\hline Loss incurred due to correction and bribery & & & \\
\hline Loss incurred due to political changes & 2.033 & 1.496 & 30 \\
\hline Design changes & & & \\
\hline Equipment failure & 1.966 & 1.325 & 30 \\
\hline Errors in design drawing & 2.066 & 1.229 & 30 \\
\hline High degree of difficulty of construction & 2.033 & 1.376 & 30 \\
\hline Stiff environmental regulations & 2.166 & 1.391 & 30 \\
\hline Incompetence of transport facilities & 1.733 & 1.112 & 30 \\
\hline Industrial disputes & 1.766 & 1.194 & 30 \\
\hline Material shortage & 1.700 & 0.952 & 30 \\
\hline Obsoleteness of building equipment & 1.666 & 1.397 & 30 \\
\hline Poor quality of procured materials & 2.100 & 1.241 & 30 \\
\hline Problems due to partner different practices & 1.766 & 1.250 & 30 \\
\hline Shortage in supply of water & 2.033 & 1.245 & 30 \\
\hline Shortage in supply fuel & 1.966 & 1.272 & 30 \\
\hline Shortage in supply electricity & 1.933 & 1.412 & 30 \\
\hline Unknown site physical condition & 1.733 & 1.460 & 30 \\
\hline Following government standards and codes & 2.000 & 1.389 & 30 \\
\hline Wastage of material by workers & 2.033 & 1.401 & 30 \\
\hline Theft of material at site & 1.933 & 1.172 & 30 \\
\hline Site distance from urban area & 2.366 & 1.425 & 30 \\
\hline Surplus material handling & 2.266 & 1.014 & 30 \\
\hline Architect Vs structural engineer disputes & 2.066 & 1.172 & 30 \\
\hline Shortage of skillful workers & 1.800 & 1.186 & 30 \\
\hline Any adverse impact on project due to climatic condition & 1.933 & 1.484 & 30 \\
\hline Any impact on environment due to project & 2.200 & 1.447 & 30 \\
\hline Healthy working environment for workers & 2.200 & 1.214 & 30 \\
\hline & 2.000 & 1.313 & 30 \\
\hline & 2.100 & 1.213 & 30 \\
\hline
\end{tabular}

Friedman mean test;

Financial Risk

\begin{tabular}{|c|c|c|c|}
\hline Rank & Name & Mean Rank & 5.20 \\
\hline 1 & Loss due to rise in fuel price & 4.08 & 1.49 \\
\hline 2 & Loss due to fluctuation of exchange rate & 4.00 & \\
\hline 3 & Insurance risk & 1.51 & \\
\hline
\end{tabular}

Legal risk

\begin{tabular}{|c|c|c|c|}
\hline Rank & Name & Mean rank & Standard deviation \\
\hline 1 & Improper verification of contract document & 3.45 & 3.00 \\
\hline 2 & Breach of contract by project partner & 1.43 & 2.95 \\
\hline 3 & Uncertainty and unfairness of code justices & 1.39 \\
\hline
\end{tabular}


Management risk

\begin{tabular}{|c|c|c|c|}
\hline Rank & Name & Mean rank & Standard deviation \\
\hline 1 & Sub contractor related problems & 10.23 & 9.35 \\
\hline 2 & Project delay & 1.43 & \\
\hline 3 & Poor relation and dispute with partner & 8.88 & \\
\hline
\end{tabular}

Market risk

\begin{tabular}{|c|c|c|c|}
\hline Rank & Name & Mean rank & 6.45 \\
\hline 1 & Increase of resettlement cost & 5.98 \\
\hline 2 & Increase of labour cost & 1.22 \\
\hline 3 & Increase of material price & 5.65 & 1.34 \\
\hline
\end{tabular}

Policy and political risk

\begin{tabular}{|c|c|c|c|}
\hline Rank & Name & Mean rank & 2.58 \\
\hline 1 & Loss incurred due to political changes & 2.52 \\
\hline 2 & Loss incurred due to correction and bribery & 1.45 \\
\hline 3 & Cost increase due to changes of government polices & 2.50 & 1.49 \\
\hline
\end{tabular}

Technical risk

\begin{tabular}{|c|c|c|c|}
\hline Rank & Name & Mean rank & Standard deviation \\
\hline 1 & Theft of material at site & 13.93 & 1.01 \\
\hline 2 & Wastage of material by workers & 13.88 & 1.42 \\
\hline 3 & Shortage of skill full labors & 13.05 & 1.44 \\
\hline
\end{tabular}

Environmental risk

\begin{tabular}{|c|c|c|c|}
\hline Rank & Name & Mean rank & \multicolumn{1}{c|}{ Standard deviation } \\
\hline 1 & Any adverse impact on project due to climatic conditions & 1.07 & 1.97 \\
\hline 2 & Any impact on environment due to project & 1.31 & 1.97 \\
\hline 3 & Healthy working environment for workers & 1.21 & \\
\hline
\end{tabular}

\section{Result and Discussions}

In this study seven important risk management factors are taken into consideration. That major factors are also having some minor factors to get a good results for risk management. Based on the statistical measures the rank correlation has been finished using SPSS software. As per the results loss due to raise in fuel price is the minor factor that affected the financial risk management. Then improper verification of contract demand is the second minor factor that affected the legal risk management factor. Third major factor is management risk and it is affected by minor factor subcontractor related problems. Market risk is the fourth factor that $\mathrm{s}$ affected by the minor factor increase of resettlement cost. The fifth major factor is policy and political risk and is affected by the minor factor loss incurred due to political changes. Theft of material at site is the minor factor that affected the major factor technical risk management. Environmental risk management is the final major factor that is affected by the minor factor any advance impact on project due to climatic condition.

\section{Conclusion}

Generally in risk management some of risk cannot be rectified due to environmental conditions like, loss due to rise in fuel price, any adverse impact on project due to climatic condition, loss incurred due to political changes these are the common risk we cannot be change. By selecting qualified contractor to overcome the subcontracted related problems, agreement should be made and follow strictly to defeat the resettlement cost and the verification on contractor documents, by providing a proper security systems to save the materials in site.

\section{References}

[1] Dikmen, M.T. Birgonul, C. Anac , J.H.M. Tah, G. Aouad "A tool for post-project risk assessment" Elsevier Vol 18 (2018) Pg 42-50

[2] Ahmet Ozats, Onder Okmen "Judgmental risk analysis process development in construction projects" Elsevier Vol 40 (2005) Pg $1244-1254$
[3] Osama Ahmed Jannadi, Salaman Almishari "Risk Assessment in Constructions" American Society of Civil Engineering Vol 10.10 (2003) Pg 492

[4] Daud Nasir, Brenda McCabe, Loesie Hartono "Evaluating Risk in Construction-Schedule Model Construction Schedule Risk model" American Society of Civil Engineering Vol 10.1061 (2003) Pg 518

[5] B.Mulholland , J.Christan "Risk Assessment in Construction Schedules" Journal of Construction Engineering And Management Vol 125 (1999) Pg 8-15

[6] Edward, J.Jaselskis "Risk Analysis Approach To Selection Of Contractor Evaluation Method" Journal of Construction Engineering And Management Vol 118 (1992) Pg 814-821

[7] Shou Qing Wang, Robert L.K Tiong "Analysis of Key Contract Clauses in China BOT Project" Journal of Construction Engineering And Management Vol 191 (1999). 